EDUVELOP

Journal of English Education and Development

Volume 1, No. 2, March 2018

ISSN 2597-713X (print)

ISSN 2597-7148 (online)

\title{
The Influence of Shiritory Game toward Improvement the Students' Vocabulary at MTS DDI Ujung Lare Parepare
}

\author{
${ }^{1}$ Hj. Nanning \\ ${ }^{2}$ Abd. Rauf Ibrahim \\ ${ }^{3}$ Nur Asiza \\ Bulqis_alfarabi@yahoo.co.id \\ STAIN PAREPARE
}

\begin{abstract}
This research is based on two major points namely fulfilling the students' need regards English vocabulary ability and on how to attract the students to be active in learning process by using media. The objectives of the research are to find out whether or not the use of shiritory game can improve the vocabulary mastery of the eight year students of MTs DDI Ujung Lare Parepare and to know the use of Shiritory Game as learning media in improving the activeness of the eight year students of MTs DDI Ujung Lare Parepare in English learning process. Besides, this research is expected can be useful reference for those who want to use media in their teaching and learning process. In this research the researcher applied class experimental design, with two classes, experiment and control class. In one class consist of four meetings. The samples of the research were 20 students from Class VIII MTs DDI Ujung Lare Parepare. After analyzing the research data, this research revealed the mean score of the students before giving treatment which reached 7.55. After giving treatment, their vocabulary mastery has increase, this was proved with the mean score 15.45. The data after pretest and posttest between experiment and control group showed that the using of Shiritory game has been influenced the students' achievement with significance Sig Value $=0.020<0.05$. Comparing with conventional games, Shiritori game is better in improving students' achievement in learning vocabulary because Shiritori game may increase students' concentration in playing it, also increase students in memorizing and spelling more new vocabularies and also make them enjoyable, fun and competitive in doing this games. It means that the using of Shiritory games has a good influence in students' learning since it helping students to develop their English language abilities.
\end{abstract}

Key words : Vocabulary, Shiritory Game 


\section{Introduction}

People use language in their daily lives as an international behavior to interact one another. Speakers formulate their utterances with the goal of having their intentions recognized and recipients process a speaker's remarks with the goal of recognizing those intentions. To do this successfully requires a variety of skills. There is basic linguistic competence, of course- the phonological, morphological, and syntactic competencies that are required to use language. However, to use language to communicate successfully requires more than linguistic competence (Kaharuddin, 2013:13).

Students' language development depends on what they experience in teaching and learning process. Teachers of English should be able to create meaningful learning activities. How learners acquire a language, Mustafa suggests that the language learners need ample exposure, engagement, and supports. $\mathrm{He}$, further, elaborates that the most serious challenges facing our English teachers include the issue of exposure to real-life English use, student engagement in real-life communicative activities, and all kinds of environmental supports, which according to research, contribute to the development of learners as communicatively competent

Vol. 1 No. 2 March 2018 users of English for communicative purposes (Mustafa. B, 2009: 16).

Schools of thought in second language acquisition ranging from structuralism/behaviorism, rationalism and cognitive psychology until constructivism have been taken as approaches. Constructivism assumes that humans generate knowledge and meaning from interaction between students' experiences and their ideas. It emphasizes the importance of the learner being actively involved in the learning process.

Constructivism is often associated with pedagogic approaches that promote active learning, or learning by doing. There are many critics of "learning by doing" as an instructional strategy. While there is much enthusiasm for constructivism as a design strategy, constructivism remains more of a philosophical framework than a theory that either allows us to precisely describe instruction or prescribe design strategies (.Http://en.wikipedia.org/w/index.php?title $=$ Constructivism).

The reality show that, teacher is now days required to be creative in teaching the four of language skills: listening, speaking, reading and writing because the skill required by students. All language has two skill, namely receptive skill and productive skill. Receptive skill consists of listening 
and reading and productive skill consists of speaking and writing. Actually, the both skills are very important for learning English but in this research, the researcher's attention focuses on one of these skills. It is vocabulary which is a part of these skills. Vocabulary plays an important role. It is one element that links the four skills of speaking, listening, reading and writing all together. In order to communicate well in a foreign language, students should acquire and adequate number of words and should know how to use them accurately.

Even though students realize the importance of vocabulary when learning language, most the students learn vocabulary passively due to several factors. First, they consider the teacher's explanation for meaning or definition, pronunciation, spelling and grammatical functions boring. Second, the students only think of vocabulary learning as knowing the primary meaning of new words. Therefore, they ignore all other functions of the words. Third, the students usually only acquire new vocabulary through new words in their textbooks or when given by teachers during classroom lessons. For example, students find many new words in a text and then ask the teacher to explain the meanings and usage. Fourth, many students do not want to take risks in applying what they have learnt. (Rafiqa, 2017) Vocabulary acquisition is a key component to successfully developing communication and literacy skills. Developing a rich vocabulary is a top priority and an on-going challenge for both

Vol. 1 No. 2 March 2018 first language and second language instruction. Whereas first language (L1) students arrive at school with a command of 2,000 to 6,000 words, most immersion students begin their academic experience at point zero.

Teaching vocabulary is one of part of subjects or materials in teaching English. It is obviously important for students. By using this game the students would not be bored and they would enjoy their materials that have been given by the teacher. Through observation at MTs DDI Ujung Lare Parepare, most of the students did not like the English subject. In this case, the students were probably not too interested to the material that is given by the teacher in order to some reasons. The first, the teacher's teaching strategy was not varied such us media, model and technique, so the students did not response to the material and the students would be bored. The second, words in English have difference between spelling and pronunciation, so the students have difficulty to read them and the last is the teacher seldom to use a game such as shiritory game.

The researchers thought that the students need something like game to release their boring or media as guidance for learning vocabulary. According to Sundayana media should be admitted as a thing which can give good contribution and optimal result in learning and teaching process (Sundayana, 2013:13). That idea would be reached when a teacher matches the media with the lesson given to students. In teaching vocabulary Universitas Sulawesi Barat 
there are many media can be used, but in this case the researcher would be applyied game as a media in teaching vocabulary, because game have advantages and effectiveness in learning vocabulary.

Games can increase the students' motivation in enriching their vocabulary easily. The game would be used in teaching vocabulary, is shiritori. Shiritory game is a Japan traditional game is a language game in which the players need to come up with a noun that begins with the final of the previous noun. Participants take turns, and the person who says a word ending or repeats a noun that has been already said loses (Shinohara, Kazuko, 2012). Shiritory is a game which is the students must be continuing that word. For example the teacher says volleyball, the first students has to look for another word which is star by the $\mathrm{L}$ word, the last word of volleyball is L. the students answer is Language and the next students shall be mentioned the new word which is begun by $\mathrm{E}$ and so on.

\section{The Literature Review}

\section{A. Vocabulary}

Vocabulary is very important for communication, it is used by all people appropriate their profession. Vocabulary in English is not all people know or understand about it expect the people live in English environment. Now, all people study English to add their knowledge through non-informal such as a course. Vocabulary is one important aspect in learning a foreign language. Without a proportional amount of vocabulary anyone will get trouble in her speaking, reading, listening, and writing. Without a shred of doubt, the researcher said that the acquisition of vocabulary would help people in gaining, understanding, and also enhancing the process of knowledgeable transferred for a better life. Indisputably the chances for progress or success in any kind of fields, like computers, technology, economy, politics, tourism, and educational increase with the size and applications of vocabulary.

Vocabulary plays important roles in mastering English.Vocabulary is essential for successful study on the secondlanguage. A vocabulary is a set of familiar words within a person's language. A vocabulary, usually developed with age, serves as a useful and fundamental tool for communication and acquiring knowledge. Acquiring an extensive vocabulary is one of the largest challenges in learning a second language (Cambridge Advanced Learners Dictionary).

Penny (1991) said, "Vocabulary can be defined, roughly, as the words we teach in the foreign language."

Meanwhile, Barnhart (2008) concluded that vocabulary is (1). Stock of words used by person, class of people, profession, etc. (2). A collection or list of words, usually in alphabetical order ad defined.

According to Harimukti Kridalaksana, vocabulary is a component of a language 
that maintains all of information about meaning and using word in a language. It is the least stable and even the least characteristic of the three components of language. Every normal person probably learnt at least three words every day, over a thousand year. This figure must be a minimum because most people had total vocabularies, which it can only be reached through even rapid acquisition of vocabulary during at least part of their life.

Learning a second language needs vocabulary as a basic to develop the student's ability in native English language. Unless they learn, a second language will add, subtract, or change any of their basic sound patterns after they reach adolescence. Grammatical constructions may increase, but a rate much slower than the increase of vocabulary.

Types of Vocabulary Schaill (1967:57) also states that every person has three types of vocabulary

1) Active vocabulary: The words that we use in speaking and writing probably runs 5.000 up to 10.000 words.

2) Reserve vocabulary : The words that we know but rarely used in ordinary speech. We use them in writing a letter when we have time to consider, or search for a synonym.

3) Passive vocabulary : the word that we recognize vaguely, but they are not sure of the meaning, however using them in either speaking or writing and we just know that we have seen before.
More specific about vocabulary division is printed out in the Encyclopedia of Education (1971; 461-462) which divided into four kinds as follow:

1) Oral vocabularies consist of words actively used $n$ speech. They are the words that come readily to the tongue of one's conversation, the more often a person uses a word, the more readily it will come to his tongue.

2) Writing vocabulary are the words that come readily to one's finger vocabulary.

3) Listening vocabulary is the stock of words to which one responds with meaning and understood in the writing of others.

4) Reading vocabulary is the words to which one responds with meaning and understanding in the writing of other.

\section{B. Media}

Word of "Media" is from Latin and it is plural form of "medium" literally means distributor or mediator. Therefore media of learning is everything which distributes message and information of learning. Sundayana (2013) argued that media in learning process is tools which is related to graphic, photographic, or electronic to catch, process and rearrange the visual and verbal information. Kinds of stimulus which can be media are human interaction, reality, voice recorded and the script, picture or silent. In above it has been explained that media of learning is everything which distribute message and 
information of learning, therefore the researchers assumes that Dice involved a media.

Functions of Media in Learning Process According to Sundayana (2013) the functions of media in learning process are:

1) As tool to distribute the message or information of lesson material to learner.

2) As one of the component around students' environment which can stimulate them to study.

Meanwhile, according to Sadiman in Sundayana (2013) stated that media has functions namely:

1) Making the message be clear and will not be too verbally.

2) Under covering the obstacle of time, place, quantity and distance.

3) Creating good mood for studying, direct interaction between students and the media.

4) Guiding the students to study independently based on their aptitude and ability of visual, auditory, and kinesthetic.

5) Giving stimulation, experience, and perception which is same

6) Creating interesting process of learning.

According to those experts, the researchers concludes that media is very useful to be used in learning process. It can create good condition in learning process, and guides the students are be interested to study.

Vol. 1 No. 2 March 2018
Therefore the researchers was sure to use media in conducting her research and hoped dice game can be good media in improving students' writing and attract them to be active.

Kinds and Characteristics of Media. According to Harjanto (2006), there are several kinds of media which may be used in learning process, they are:

1) Graphic media such as picture, photo, graphic, frame, and diagram, poster, cartoon, comic, etc. Graphic media is commonly called as two dimensions media, which has length.

2) Three dimensions media is the media which has certain model such as solid, longitudinal, series, mock up, diorama.

3) Projection media such as slide, filmstrip, film, $\mathrm{OHP}$, etc.

4) Environment as learning media.

Understanding of media characteristic is basic ability which has to be mastered by teacher regards to the choosing of media. Therefore in choosing a media, many things should be thought, such as the correlation between the function of media and the things that we are going to do, and the purpose of using media.

\section{Shiritory Game}

Shiritori is a kind of word chain game originated from Japan. Like most word chain game, the game is played by chaining the word; the last syllable of the previous 
word becomes the first syllable of the next word.

According to Wikipedia Shiritory (literally "bottom taking") is a language game in which the players need to come up with a noun that begins with the final of the previous noun. Participants take turns, and the person who says a word ending or repeats a noun that has been already said loses.

Conversing about game, there are a lot of researches have proved that games can improve students studying motivation and creativity. Four of those researches are explained such following:

1) English Language Programs Bureau of Educational and Cultural Affairs United States Department of State Washington, D.C.The result of the research is put down on book entitled Activate: Games for Learning American English. On that book stated that "Games offer students many benefits, including opportunities to develop social skills, to learn coping strategies (It can be hard to lose!), and to keep their minds active. Activate is designed to provide these benefits while helping students to develop their English language abilities" (Moursund, 2007).“Games have contributed significantly to my informal and formal learning. Playing games that involved two or more people was an important component of my social development and social life. Game playing was such an important part of my childhood that I made sure it was a part of my children's childhoods".

2) Carabajo (2011:3) in her monograph entitled Game as Communicative activities to encourage Oral Production in Children from Ages 10 to 11 avowed that many students feel much more comfortable to study when game are involved.

Based on the quotations, there are a numbers of arguments which agree that applying game in learning and teaching process is very beneficial that researchers cannot be mentioned one by one. Those people who argued above also use shiritory game as one of their media and game in learning vocabulary.

Figure 2 : the shiritory game picture

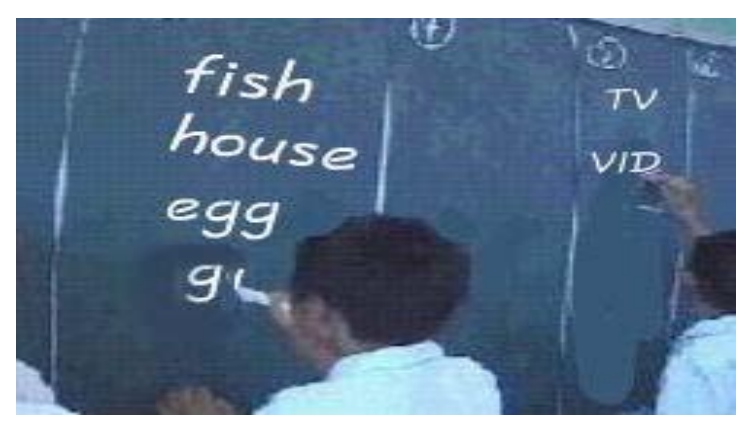

The rules of shiritory game from Basic rules:

1) The students cannot be allowed to repeat the word.

2) The game was begun by the first students by saying a word (for example about health).

Vol. 1 No. 2 March 2018
EDUVELOP

Journal of English Education and Development Universitas Sulawesi Barat 
3) The students would be losing if saying the same word which had said before and saying the person name.

The rules of shiritory game from Local rules:

1) The word only limited on the specific theme, such us flower, fauna, health, recreation, train station, city and country.

2) The students would be lose if cannot find the word to say after the time is over.

3) The looser students cannot be joined again in the next game.

\section{The procedure of Using Shiritory Game.}

The procedure of using shiritory game is the first player says a word, the second player must say a word beginning with the last letter of the first player's word, the third player say a word beginning the last letter of the second player's word and so on. The players are not supposed to say the same word twice. The teacher (or anyone really) chooses a word e.g. "dog", and throws a ball/soft toy to the next player. The next player must think of a word beginning with the last letter of the previous word e.g. "good" and so on.

Clockworkgrue (2001) also says many technique can be used to play the shiritori games, example :

1) Split the class into two groups and the teacher pronounces a vocabulary word. Group A tries to find a vocabulary word which starts with the last letter of the vocabulary the teacher just pronounced.

Vol. 1 No. 2 March 2018
After group A pronounces, group B pronounces a vocabulary word with starts with the last letter of the word group A just pronounced. The group that cannot find the vocabulary word will lose.

2) This is writing shiritori by oneself. Students continue shiritori by themselves by writing. (some students can say vocabulary words and know its meaning, but cannot write it correctly)/

3) Split the class into several groups and have them decide the order. The first students line up in front of the board and write out all the vocabulary that starts with the letter a teacher says for a limited time. When the time comes, the next student in each can continue it or the teacher gives them a different letter, etc.

\section{Theoretical Framework}

Constructivism which is popularly by Piaget is basically a theory based on observation and scientific study about how people learn. It says that people construct their own understanding and knowledge of the world, through experiencing things and reflecting on those experiences. When we encounter something new, we have to reconcile it with our previous ideas and experience, maybe changing what we believe, or maybe discarding the new information as irrelevant. In any case, we are active creators of our own knowledge. To do this, we must ask questions, explore, and assess what we know. 
In the classroom, the constructivist view of learning can point towards a number of different teaching practices. In the most general sense, it usually means encouraging students to use active techniques (experiments, real-world problem solving) to create more knowledge and then to reflect on and talk about what they are doing and how their understanding is changing. The teacher makes sure she understands the students' preexisting conceptions, and guides the activity to address them and then build on them. According to Bruner there are tree learning modus, they are enactive, iconic and symbolic. Enactive is doing, for example the students will give word cake, it will be understood directly to make a cake. The second step is iconic. After giving label image, the word of cake is studied by the picture asssssnd lastly is symbol. The students will read or listen to the word of cake and try to match with their experience in making cake (Cecep Kustandi and Bambang Sutjipto, 2011).

The theory is a base for the teacher to make a material. The vocabulary material and shiritori games as materials that applied by the researchers in the classroom which will be used to teach and to stimulate the students on vocabulary. And the students as the object which need to develop their vocabulary.

In treatment process, the researchers will use shiritori games in teaching vocabulary. The researchers will give the material in four meeting.

Vol. 1 No. 2 March 2018
1) On the first meeting, the researchers gave the material about health

2) On the second meeting, the researchers gave the material about recreation.

3) On the third meeting, the researchers gave the material about Flora and Fauna

4) On the four meeting, the research gave the material about Seasons

In this research, the researchers expected to develop the student's vocabulary. The students who had learn vocabulary through shiritori games would be getting much better than before.

\section{Research Method}

This research will be empleyed a quasiexperiment design which is applied non equivalent control group design.

This research was conducted in MTs DDI Ujung Lare Parepare, in academic year 2017/2018. The school is located on Jalan Abu Bakar Lambogo, District of Soreang, Parepare. The population of this research was the eight students of MTs DDI Ujung Lare Parepare. There are four classes, consist of class $A=20$ students, class $B=20$ students, class $\mathrm{C},=20$ students, and class $\mathrm{D}=19$ students and the total number of the population are 79 students. In this research, the researchers used purposive sampling technique. The sample of the research is taken from two classes, class A was experiment group and class B was control group. So the total sample are 40 students. Planning and action were in the step of research. 
Instrument will be used in this research are observation list and achievement test. Observation test is used to observe in learning process. Test achievement is used to measure the students' achievement by using multiple choices. The table can be shown below:

Table 1: the Shiritory game's instrument

\begin{tabular}{|c|c|c|}
\hline Variable & Sub variable & Indicator \\
\hline \multirow{4}{*}{$\begin{array}{c}\text { Shiritory } \\
\text { Game }\end{array}$} & Health & \multirow{4}{*}{$\begin{array}{l}\text { The students } \\
\text { will be } \\
\text { continuing and } \\
\text { finding some } \\
\text { new words by } \\
\text { using the } \\
\text { shiritory game }\end{array}$} \\
\hline & Recreation & \\
\hline & Flora and fauna & \\
\hline & Seasons & \\
\hline
\end{tabular}

Table 2: the conventional media's instrument

\begin{tabular}{|c|l|l|}
\hline Variable & Sub variable & \multicolumn{1}{|c|}{ Indicator } \\
\hline \multirow{5}{*}{$\begin{array}{c}\text { Conventional } \\
\text { Media }\end{array}$} & $\begin{array}{l}\text { Kegiatan } \\
\text { awal }\end{array}$ & $\begin{array}{l}\text { Menerima } \\
\text { penjelasan } \\
\text { guru tentang } \\
\text { tujuan } \\
\text { pembelajaran } \\
\text { Apersepsi }\end{array}$ \\
\cline { 2 - 3 } & Kegiatan inti & $\begin{array}{l}\text { Menerima } \\
\text { penjelasan } \\
\text { materi oleh guru } \\
\text { (ceramah) }\end{array}$ \\
\cline { 2 - 3 } & $\begin{array}{l}\text { Penarikan } \\
\text { kesimpulan } \\
\text { Evaluasi } \\
\text { Tindak lanjut } \\
\text { (penugasan) }\end{array}$ \\
\hline
\end{tabular}

Table 3: the Students' achievement instrument

\begin{tabular}{|c|c|c|}
\hline $\begin{array}{c}\text { Based } \\
\text { Competence }\end{array}$ & Indicator & $\begin{array}{l}\text { Total } \\
\text { Item }\end{array}$ \\
\hline
\end{tabular}

Vol. 1 No. 2 March 2018

\begin{tabular}{|l|l|c|}
\hline \multirow{5}{*}{} & $\begin{array}{l}\text { The students can answer } \\
\text { the test about health, } \\
\text { recreation, seasons and } \\
\text { flora and fauna by } \\
\text { multiple choice }\end{array}$ & 10 \\
\cline { 2 - 3 } $\begin{array}{l}\text { Finding new } \\
\text { words by } \\
\text { using } \\
\text { shiritory } \\
\text { game }\end{array}$ & $\begin{array}{l}\text { The students can } \\
\text { translate into Indonesian } \\
\text { about health, recreation, } \\
\text { seasons and flora and } \\
\text { fauna }\end{array}$ & \multirow{2}{*}{10} \\
\cline { 2 - 3 } & $\begin{array}{l}\text { The students can match } \\
\text { the word about health, } \\
\text { recreation, seasons and } \\
\text { flora and fauna. }\end{array}$ & 5 \\
\cline { 2 - 3 } & $\begin{array}{l}\text { The students can fill in } \\
\text { the blank about health, } \\
\text { recreation, seasons and } \\
\text { flora and fauna }\end{array}$ & 5 \\
\hline
\end{tabular}

\section{Discussion}

This section provides the discussion about the finding that showed in the previous section. The discussion of this research provides insight about the (1) significance influences of Shiritory game toward vocabulary improvement of the eight year students of MTs DDI Ujung Lare Parepare (2) Significance influences of Conventional media toward vocabulary improvement of the eight year students of MTs DDI Ujung Lare Parepare and (3) the learning achievement differences between the students' who teach by Shiritory game and the students' who teach by conventional media of the eight year students of MTs DDI Ujung Lare Parepare

\section{A. Significance influences of Shiritory game toward vocabulary improvement}


of the eight year students of MTs DDI Ujung Lare Parepare.

In teaching vocabulary there are many media can be used, but in this case the researchers would be applyied game as a media in teaching vocabulary, because game had advantages and effectiveness in learning vocabulary. Game can increase the students' motivation in enriching their vocabulary easily.

From the data, the students are good in learning vocabulary after the teacher used Shiritory games in the class. The data showed that the students improvement after learning Shiritory game was highly improve. The control students' score in pretest was 11.15 ; meanwhile, score in posttest was 12.40. The experiment students' score in pretest was 7.55; meanwhile, score in posttest was improved at 15.45. it was supporting by applying paired samples test formula that if sig value in $(2$-tailed $)=0.000<0.05,(0.000$ is the lowest than alpha 0.05), it means that there were significance influences the use of shiritory game toward improvement the eight students' vocabulary at MTs DDI Ujung Lare Parepare. The researchers concluded that there are significance improvement between experiment and control students in learning vocabulary through Shiritory games and conventional media.

As Carabajo stated in her monograph entitled Game as Communicative activities to encourage Oral Production in Children

Vol. 1 No. 2 March 2018 from Ages 10 to 11 avowed that many students feel much more comfortable to study when game are involved. In learning vocabulary, teacher should apply many technique and enjoyable games in order to improve students' achievement. Since media are very important in learning process, it is also as one of the component around students' environment which can stimulate them to study. The enjoyable and appropriate games as media in teaching vocabulary takes place in stimulating students' interest and participating in learning.

Mel Silberman in his book entitle Active Learning wrote that the students are funny in learning if they are active in learning. One of them is using game in learning. Game can improve the students' concentration, attention and their activeness in learning English.

\section{B. Significance influences of Conventional media toward vocabulary improvement of the eight year students of MTs DDI Ujung Lare Parepare.}

The use of conventional media in control group, it was not effective to improve the eight students' vocabulary at MTs DDI Ujung Lare Parepare. From the data showed that the control students' score in pretest was 11.15; meanwhile, score in posttest was 12.40. Based on the data the lowest number is at interval 15-17 and 18-20 because only 1 student got the value at that interval in classification good and excellent. While the Universitas Sulawesi Barat 
highest number is at interval 9-11 as many as 7 students who scored at that interval with classify was poor.

Meanwhile in data of Posttest, there are 1 student got score at intervals 2-5, 3 students got the score at interval 6-9, 5 students took the value at interval 10-13, 10 students got grades on interval 14-17 and 1 student got score on interval 18-21. So from the data the lowest number is at interval 2-5 because 1 student got the value at that interval in very poor classification, on interval 18-21 (5\%), 1 student got excellent classification. While the highest number is at interval 1417 as many as 10 students who scored good classification.

To measure control group, the researchers was applying paired samples test formula with sig value in (2-tailed) $=0.207>0.05$, (0.207 is the highest than alpha 0.05), it means that there were not significance influences the use of conventional media toward improvement the eight students' vocabulary at MTs DDI Ujung Lare Parepare.

The researchers could be saying that using shiritory game can improve the eight students' vocabulary at MTs DDI Ujung Lare Parepare than using conventional media in learning vocabulary.

\section{Learning Achievement differences between the students' who teach by Shiritory game and the students' who teach by conventional media of the}

Vol. 1 No. 2 March 2018

\section{eight year students of MTs DDI Ujung Lare Parepare}

Since games as media is important in improving students' achievement in learning, the using of interesting media game become one of way in teaching vocabulary. Based on its function, the game in learning process can be a guide for the students in studying independently based on their attitude and ability of visual, auditory, and kinesthetic.

From the data, the students' achievement after learning vocabulary by using Shiritory and conventional games were highly improved. Applying independent samples test, showed that the result was $0.020<$ $0.05,(0.020$ is the lowest than 0.05$)$. The data after pretest and posttest between experiment and control group showed that the using of Shiritory game had a big significance towards students learning achievement. Comparing with conventional game, Shiritori game is better in improving students' achievement in learning vocabulary because Shiritori game may increase students' concentration in playing it, also increase students in memorizing and spelling more new vocabularies and also make them enjoyable, fun and competitive in doing this games. It means that the using of Shiritory games had a good influence in students' learning since it helping students to develop their English language abilities.

Teaching vocabulary by using Shiritori games also makes students feel more fun and enjoy in learning vocabulary in the 
classroom. Learning vocabulary by using word games also can encourage students to interact and communicate with their friends and teacher. Besides that, they also feel more motivate and challenging in learning vocabulary since it can help them to make and sustain the effort of learning.

To sum up, the Shiritory game had many benefits in improving students' achievement in learning vocabulary. Not only fun, but also it can be a good media that teacher should had in learning process. By applying Shiritory games, the students may know many new vocabularies without forgetting the previous vocabularies that they had been learned.

As Ikuyo Ishizaka, Mari Higashikawa, Yuki Hara, Wakana Hata, Keiko Suzuki in their research entitled Development of word fluency and expressive vocabulary in Japanese kindergarten children reported that this study examined the expressive vocabulary of young children in Japan in the middle and senior years of kindergarten by using the ISF method. Results show a difference between 5- and 6-year-olds in terms of the number of words expressed and the size of the observed vocabulary. Nouns were the most common type of word recalled by the children. By comparing these results with those of two earlier studies conducted approximately 30 years ago in Japan, our findings indicated that many of the same words are still the most frequently recalled words by young children. These results provide invaluable data on children's language acquisition and

Vol. 1 No. 2 March 2018 further our understanding of how young and healthy children acquire different types of vocabulary items. Results also provide possible implications for work in other areas, such as developing an assessment for children with language and developmental disorders.

\section{Conclusion}

Based on the above descriptions, it can be concluded that: the students' achievement after learning vocabulary by using Shiritory and conventional games were highly improved. Applying independent samples test, showed that the result was $0.020<$ 0.05 , (0.020 is the lowest than 0.05). The data after pretest and posttest between experiment and control group showed that the using of Shiritory game had a big significance towards students learning achievement. Comparing with conventional game, Shiritori game is better in improving students' achievement in learning vocabulary.

\section{Reference}

Anonym. 2013. Activate Games for Learning American English. Washington D.C: English Language Programs Bureau of Educational and Cultural Affairs United States Department of State Washington, D.C

Ayuningtyas, Bety Dwi and Wulyani, Anik Nunuk. 2012. Using Picture Sequences to Improve the Ability of Eleventh Graders at SMAN 1 Srengat-BlitarIn Writing Narrative Texts. Accessed on October 3 2015, 
retrieved from http://jurnal-online.um.ac.id/data/artikel/artikel637D0BAC482D981925210404FD9CCF72.pdf

Brany Quote. 2001-2014. Picture. Accessed on March, 9, 2014. From http://www.braniquote.com/words/pi/picture

Carbago, Angelica R. 2011. Game as Communicative Activities to Encourage Oral Production in Children from Ages 10 to 11 [Monograph]. Accessed on February 15 2015, from: http://dspace.ucuenca.edu.ec/bitstream/123456789/2108/1/tli305.pdf

Chinh, Sheu Hsiu. 2009. EFL Children's Views on English Picture Story Books. 9 (215234) (online),( http://www.asian-efljournal.com, accessed on March 28 22015).

Departemen Pendidikan Nasional. 2003. Kurikulum 2004; Standar Kompetensi; Mata Pelajaran Bahasa Inggris; Sekolah Menengah Atas dan Madrasah Aliyah. Jakarta: Balitbang Depdiknas.

Gay, L. R., et al. 2006. Educational Research: Competencies for Analysis and Application: Eighth Edition. Columbus Ohio: Pearson Merril Prentice Hall.

Harjanto. 2006. Perencanaan Pengajaran. Jakarta: PT. Andi Mahasatya

Handoko, teguh. 2010. Rahasia SUKSES Belajar Bahasa Inggris dengan Mudah Tanpa Melalui GRAMMAR

Vol. 1 No. 2 March 2018 yang Membosankan.Jakarta: eCompusoft Training Centre

Harmer, Jeremy. 2002. The Practice of English language teaching. ${ }^{\text {rd }}$ completely Revised and updated. Cambridge, UK: Longman.

Hibbing, Anne Nielsen \& Erickson, Joan L. Rankin. 2013. Picture is Worth a Thousand Words Using Visual Image to Improve Comprehension for Middle School Struggling Readers.56(8).(online) (http://currins545.pbworks.com/w/file/fetch/77717024/Hibbing$\% 20 \% 282003 \% 29 \% 20$ Visualizing\%20for\%20struggling\%20readers,Pdf

Ikuyo Ishizaka, Mari Higashikawa, Yuki Hara, Wakana Hata, Keiko Suzuki 2014. Development of word fluency and expressive vocabulary in Japanese kindergarten children. Accessed on November 17, 2017, from http://mlib.kitasatou.ac.jp/homepage/ktms/kaishi/pdf/K MJ44-1/KMJ44-1p026-030.pdf. Department of Rehabilitation, Speech Therapy Course, School of Allied Sciences, Kitasato University.

Macmilan Dictionary. 2014. Specific Types of Picture or Work of Art. Retrieved March $28 \quad 2015$, from http://www.macmilandictionary.com/t hesaurus-category/british/specifictypes -of-picture-or-work-of-art

Mahardhita, Shinta. 2013. Bermain Dadu Ajaib Belajar Kosakata BahasaInggris. Accessed Januari 01 2015, retrieved from: http://belajar.indonesiamengajar.org/2013/02/bermain-daUniversitas Sulawesi Barat 
du-ajaib-belajar-kosakata-bahasainggris/

Moursund. 2007. Introduction to Using Games in education: A Guide for Teachers and Parents. Accessed on February 15 2015, retrieved from: http://pages.uoregon.edu/moursund/Books/Games/Games.pdf

Oxford dictionary. 2008. Oxford Learner's Pocket Dictionary. China: Oxford University Press.

Richards. Jack.C. \& Renandya. Willy. A. 2002. Methodology in Language Teaching: An Anthology of Current Practice. USA: Cambridge University Press.

Silberman, Mel. 2009. Active Learning: 101 Strategi Pembelajaran Aktif. Yogyakarta: Pustaka Insan Madani.

Sundayana, H. Rostina. 2013. Media Pembelajaran Matematika (untuk Guru, Calon Guru, Orang Tua, dan Para Pecinta Matematika). Bandung: Alfabeta .

Tiro, Arief. 2004. Dasar- Dasar Statistika (Edisi Kedua). Makassar: Andira Publisher.

Urquhat, Vicki \& Monette Mclver. 2005. Teaching Writing in The Content Areas.United Stated of America: ASCD

Weigle. Sara Chusing. 2002. Assessing Writing. UK: Cambridge University Press

Zechman, Megan. 2014. How to Improve Creating Writing Skill with A Game.
Accessed on January $5^{\text {th }} 2015$, From http.//educationpossible.com/improve-creative-writing-skills-game

Ahmad. Application of Community Language Learning Through Group Work Activity in Teaching Speaking. Parepare: Unpublished Thesis. 2013.

Clockworgue. Shiritory (www.everything2.com). Accessed on 28 march 2001 Cambridge Advanced Learners Dictionary.

Dirjen Pendidikan Dasar dan Menengah. Peraturan Direktorat Jenderal Pendidikan Dasar dan Menengah Tentang Penilaian Perkembangan Anak Didik. Jakarta: Depdikbud. 2005.

Gay, L. R., et al. Educational Research Competencies for Analysis and Applications:Eight Edition. Columbus Ohio: Pearson Merril Prentice Hall. 2006

Gay, L. R. Educational Research; Competencies for Analysis \& Application (Second Edition). Charles E. Merril Publishing Company.:A bell \& Howell Company. 1981

Harjanto. Perencanaan Pengajaran. Jakarta: PT. Andi Mahasatya. 2006.

Http://www.aminlimpo.com/2016/12/words -chains-games-in-vocabulary.html. Accessed on 20 April 2017

Http://arlingsapri.blogspot.co.id/2014/03/co ntoh-proposal-vocabulary.html accessed on 20 April 2017 
Http://en.wikipedia.org/w/index.php?title= Constructivism(learningtheory, accessed on May 04th 2014)".

Kaharuddin. The Communicative Competence-Based English Language Teaching. Yoyakarta: Trust Media. 2013.

Rafiqa. 2017. "THE ENGLISH VOCABULARY ACQUISITION OF THE STUDENTS OF STATE JUNIOR HIGH SCHOOL 2 PAREPARE." EDUVELOP (Journal of English Education and Development) 1 (1):18-35. ojs.unsulbar.ac.id/index.php/eduvelop.

Shinohara, Kazuko. "Designing Language Games" (PDF). Special Issue of Japanese Society for the Science of Design 2012. Accessed on 20 April 2017.

Sundayana, H. Rostina. Media Pembelajaran Matematika (untuk Guru, Calon Guru, Orang Tua, dan Para PecintaMatematika). Bandung: Alfabeta . 2013. 